\title{
Public Sector Labour Relations in the United States: Austerity, Politics and Policy
}

\begin{abstract}
Public sector unions around the world are under threat from political forces. Combined, the financial crisis and austerity measures have challenged public sector unions' legitimacy. In the U.S., the postrecession assault on public sector unions is rooted in political ideology, with not only a widening polarization along the liberal-conservative spectrum playing a key role, but cultural cognition and economic downturn, too. This research provides a comparative historical analysis of changes in public sector collective bargaining rights at state and local levels in 50 states. The article describes the variations in public sector industrial relations at the state and local levels in the short and medium term. It also proposes a theoretical model to explain similar and diverging patterns which can be observed across the states.
\end{abstract}

Keywords: public sector labour relations, United States, austerity, regional differences (JEL: H61, H62, H63, J51, J52, J53, L32)

\section{Arbeitsbeziehungen des öffentlichen Sektors in den Vereinigten Staaten: Austerität, Politics und Policy}

\section{Zusammenfassung}

Gewerkschaften des öffentlichen Dienstes sehen weltweit ihre Legitimation in Frage gestellt und sind bedroht durch politische Gegner, die Finanzkrise und Sparmaßnahmen. In den USA wurzelt der Angriff auf die Gewerkschaften des öffentlichen Dienstes in politischer Ideologie, insbesondere der zunehmenden Polarisierung im liberal-konservativen Spektrum, dem Feld der kulturellen Kognition und des wirtschaftlichen Abschwungs. Der Beitrag liefert eine historisch-komparative Analyse der Veränderungen Rechte des collective bargaining im öffentlichen Dienst auf staatlicher und lokaler Ebene aller 50 Staaten der USA. Dabei werden die kurz- und mittelfristigen Veränderungen der industriellen Beziehungen des öffentlichen Dienstes auf staatlicher und lokaler Ebene beschrieben und darüber

* Patrice M. Mareschal, Ph.D., Department of Public Policy \& Administration, Rutgers University, USA, Email: marescha@camden.rutgers.edu

** Artikel eingegangen: 02.08.2016, revidierte Fassung akzeptiert nach doppelt-blindem Begutachtungsverfahren: 09.06.2017 
hinaus ein Modell zur Erklärung von Ähnlichkeiten und Abweichungen zwischen den Bundesstaaten vorgeschlagen.

Schlagwörter: Arbeitsbeziehungen des öffentlichen Sektors, USA, Austerität, regionale Differenzen

\section{Introduction}

Public sector labour unions exist at the intersection of work, public policy, and public values. As a result, public sector unions in industrialized countries occupy a unique position of power. The sources of power include: politicians, voters, and the state's role in the economy as a distributor and overseer of public goods and services (Dixon \& Martin, 2012). The public sector's reliance on tax revenues to fund public goods and services means that employers may prioritize factors such as social well-being in making employment decisions rather than purely financial factors.

In the private sector, maintaining union-free status translates into greater profits for businesses. Moreover, private sector managers are more likely to be terminated or have their career advancement stalled if a union organizing drive takes place on their watch (Freeman \& Kleiner, 1990). In contrast, public sector managers are more likely to involve employees in collaborative decision making (Morse, 2008) and less likely to reap a direct financial benefit from opposing unions. Hence, public sector managers have fewer incentives to oppose unions than managers in the private sector do (Kearney \& Mareschal, 2014).

Public sector workers differ from their private sector counterparts in several important ways. Public sector workers in the U.S. are much more likely to be represented by unions than are workers in the private sector. In 2015, union representation in the state and local public sector was 39 percent. In contrast, only 7.5 percent of workers in the private sector were covered by collective bargaining agreements in 2015 (Bureau of Labor Statistics, 2016).

Women and minorities make up a greater percentage of the public sector workforce than of the private sector workforce. In 2014, women comprised 60 percent of the state and local workforce as compared to 47 percent in the private sector. Likewise, 13 percent of state and local government employees were African American compared to about 11 percent in the private sector (Current Population Survey, 2014).

The public sector has more professional jobs and fewer low-skilled jobs than the private sector. On average, public sector workers are better educated compared to private sector employees. Over half of full-time state and local public sector employees hold at least a four-year college degree compared to about a third of full-time employees in the private sector (Lewin, Kochan \& Keefe, 2012).

Some of these patterns hold true in other western industrialized democracies as well. For example, public sector unions in the U.K. have greater strength than private sector unions as measured by membership and density (Barratt, 2009). Also like in the U.S., the public sector workforce in the U.K. includes more women and its members have greater levels of education and professionalization (Matthews, 2010). In Canada, 70 percent of public sector workers are members of unions. Similarly, the public sector labour movement in Canada consists of more women, professional, and white collar workers than the private sector labour movement (Ross \& Savage, 2013). 
Yet, public sector unions in the U.S. generally operate in a hostile environment. In particular, they lack the institutional protections provided elsewhere in the world. Public sector unions in the U.S. never achieved the status of "social partners" at the national level like their counterparts in Europe (Hyman, 2005). To illustrate, in the U.K. the Whitley Report implied that the government should serve as a "model employer" by setting policies that allowed working people to improve their standard of living (Carter \& Fairbrother, 1999). The Whitley Report helped create a system of collective bargaining with joint consultation between government employers and unions at the national level and regional joint councils at the local government level (Corby \& Symon, 2011). In contrast, the U.S. neglected to establish comparable goals for government employers.

The labour movement in the U.S. has remained vital largely because public sector unions increased membership while private sector unions were faltering. One of the main political benefits of public sector unions is that they have members in most states and Congressional districts (Wilson, 2012). The primary drawback of this shift to state and local government as the arena for American unionism is that with the weakening of private sector unions, public sector union members are pitted against residents and homeowners. This group of stakeholders has an interest in minimizing the cost of state and local government in order to keep their tax burden low (Goldfield \& Bromsen 2013).

In keeping with the themes of continuity, change, and crises, this paper traces the emergence of public sector unions in the U.S. and contemporary challenges to the public sector labour movement posed by state and local government responses to the financial crisis of 2008. This study uses historical comparative analysis to describe the variations in public sector industrial relations at the state and local levels. In addition, it offers a theoretical explanation for similar and diverging patterns of response to economic shocks across the states. The conclusion discusses ongoing challenges for organized labour, the implications for democracy, social, and economic well-being, and the balance of power between management and workers.

\section{A Brief History of Public Sector Unions}

\subsection{Arrested Development}

Although several public sector unions were established in the late 1800s and early 1900s, they did not really begin to gain strength until the 1960s. Several factors limited the growth of public sector unions early on: the sovereignty argument, the nature of government employment, and an intolerant legal environment (Kearney \& Mareschal, 2014). Opponents of public sector unions maintained that bargaining with public employees would distort representative democracy by putting the demands of public employees ahead of the demands of other citizens and stakeholders (Malin, 2012). In essence, the doctrine of sovereignty was used to portray collective bargaining as an illegal delegation of citizens' self-determination. Members of the conservative movement continue to frame their opposition to public sector unions as a sovereignty issue today.

The composition of the state and local government workforce also played a role in the public sector unions' pace of development. With the implementation of the merit system 
during the progressive era, public employment became increasingly professionalized. The merit system provided security and protections against management abuses and served as a form of union substitution. In addition, women and minorities were drawn to public employment in the 1960s and 1970s as an attractive alternative to private sector employment (McCartin, 2006). Traditionally the U.S. labour movement has faced challenges organizing workforces with substantial numbers of white collar employees, women, and minorities.

Moreover, the legal environment was not conducive to public sector bargaining. Public employees' early attempts to form and join unions were often thwarted by the legal precedent set in 1892 by the Massachusetts Supreme Court in McAuliffe v. the City of New Bedford. In that case Justice Holmes argued that public employees forfeited their right to organize as a condition of accepting public employment (Kearney \& Mareschal, 2014). The Boston police strike of 1919 further dampened the prospects of public sector unionism. The National Guard was called in to put down the strike and violence erupted. Many local governments responded by banning all types of public sector unions (Slater, 2013). Justice Holmes' arguments endured and were utilized as recently as 1963 by the Michigan Supreme Court in the case of AFSCME Local 201 v. City of Muskegon to prevent police officers from forming a union (Malin, 2012).

\subsection{The Rise of Public Sector Unions}

The legal framework protecting workers' rights to participate in workplace decisions and join together for mutual aid in the private sector was established with the passage of the National Labor Relations Act (NLRA) of 1935. However, the NLRA excluded federal, state, and local governments from coverage. Collective bargaining rights in the public sector were established nearly three decades later and differ across sectors of the government.

Although the public sector lagged behind the private sector in establishing collective bargaining rights, public sector unionism grew dramatically beginning in the 1960 s and 1970s. This was due in part to the passage of laws that protected collective bargaining at the state and local levels. Wisconsin was the first state to pass a public sector collective bargaining law in 1959. Other states soon followed suit. By the late 1970s, a majority of states had enacted laws permitting collective bargaining for at least some public sector employees (Slater, 2013).

The rise of public sector unions was accelerated by the build-up of grievances and pressures combined with shocks to the system (Goldfield \& Bromsen, 2013). Viewed in this way, the development of public sector labour unions was a natural response to conflicts. A variety of factors spurred public sector organizing including a growth in government, private sector spillover effects, and social change.

At the national, state, and local levels government budgets grew after WWII. As a result, administrative units expanded rapidly, especially in public education. Large, concentrated government employment units facilitated union organizing (Goldfield, 1989). In terms of spillover effects, public sector unions' success in organizing members and negotiating contracts was tied to strength in the private sector labour movement. Specifically, the private sector unions helped legitimatize the public sector's demands and build political support (Cantin, 2012). Over this time period large numbers of young people and minorities entered the public service. Both groups were receptive to unionization (Barrett, 1973). 


\subsection{Contemporary Challenges to the Public Sector Labour Movement}

As noted earlier, with the weakening of private sector unions, public sector union members have become caught up in a class war in which they are pitted against taxpayers. Conservatives contend that the fiscal problems of state and local governments are caused by inefficient government and selfish public sector unions who bargain for excessive pay and benefits for their members. These challenges are driven by the reinventing government movement and a changing economy which exacerbates income inequality.

The reinventing government movement gained traction around the world in the early 1990s. Regardless of location, the common conceptual thread is anti-government bias. The reinventing government movement made it acceptable for politicians, practitioners, and academics to advocate weakening public sector unions, shrinking government, and sanctioning public servants (Hood, 1991). It is rooted in a political ideology aimed at disempowering public employees and undermining the career civil service (Kearney \& Hays, 1998).

Adherents of the movement advocate outsourcing and decentralization to diminish the size and scope of government, and managerialism to make public employees more similar to private sector employees. For example, the Director of Georgia's Commission on Privatization noted that the civil service system was rigid and inflexible, and went on to say, "We don't believe that public employees should have any protection that the private employees don't have ... Why should government be any different?" (Hansen, 1995, p. 16). Taken together, outsourcing, decentralization, and managerialism strengthen the role of the private sector in providing public services and reallocate power from the legislative to the executive branches of government (Kearney \& Hays, 1998).

Proponents of outsourcing at the local government level contend that it promotes efficiency, equity, and local voice. However, Hefetz, Warner, and Vigoda-Gadot (2012) find that local government outsourcing efforts produce lacklustre results regarding voice, efficiency, and equity. Instead, local governments use contracting to replace full-time public employees with less expensive part-time employees and circumvent civil service protections for public employees (Fernandez, Smith \& Wenger, 2007). The degree of outsourcing in local governments ranges from a small subset of services to what is known as extreme contracting in which all services are outsourced and only a handful of in-house staff are retained (Bradbury \& Waechter, 2009).

At the level of state government, the executive branch tends to lead the reform efforts (Brewer \& Kellough, 2016). For governors, the primary goal of reform efforts is to gain greater political control over public employees. The tactics used to achieve this goal are to reduce civil service protections for public employees, increase managerial discretion, implement pay-for-performance systems, and transfer governmental functions to private contractors (Barzelay, 2001; Hood, 1991). For example, Governors Zell Miller in Georgia, Jeb Bush in Florida, and Mark Sanford in South Carolina championed radical civil service reforms that combined decentralization and at-will employment (McGrath, 2013). All of these reforms raise concerns about constitutional provisions for equal protection and due process, yet they have frequently been implemented with little systematic investigation of their impact on core personnel management functions (Jordan \& Battaglio, 2014).

Public sector unions also face challenges due to rising inequality brought on by a changing economy. During the Great Recession (2007-2009), workers in middle-skilled 
white- and blue-collar positions experienced severe job losses. Over the same time period, employment in highly-skilled white-collar fields such as professional, managerial, and technical positions remained stable. Employment in low-skilled service sector occupations such as food service, housekeeping, and personal care also held steady (Autor, 2010). This polarization in employment is not unique to the U.S. Similar trends are evident in the European Union (Autor, 2010; Goos, Manning \& Salomons, 2009).

Workers with less than a bachelor's degree make up 67 percent of the adult population in the U.S. (Ryan \& Bauman, 2016). The loss of middle-skill, blue-collar jobs has been especially detrimental to men with low levels of education. The remaining job prospects open to them are primarily concentrated in low-wage service occupations (Autor, 2010). Displaced male workers in the U.S. have not adapted well to the changing economy. That is, they have not pursued higher education and have balked at taking service sector jobs they perceive as women's work. Moreover, they have expressed anger and resentment towards women, African Americans, and public sector workers, whom they perceive as having an unfair advantage in economic progress (Hochschild, 2016).

After the financial crisis of 2008, Republican governors and the conservative movement used this polarization to fuel a politics of resentment among citizens. Specifically, Republicans and their corporate allies have portrayed public sector workers as a privileged class that enjoys better pay and benefits than private sector workers (Cantin, 2012; McCartin, 2012). Similarly in Canada, public sector unions have been cast as greedy villains who threw the government into debt and are therefore to blame for austerity policies (Ross \& Savage, 2013). This framing of the argument encourages the working class and taxpayers to direct their anger over the changing economy towards public sector unions instead of the financial industry which played a key role in triggering the Great Recession.

\section{The Public Sector Collective Bargaining Environment Today}

\subsection{Political Context}

At the state and local levels, public sector unions have traditionally formed alliances with Democratic politicians. The labour movement in the U.S. evolved into a social democratic bloc in the political arena that successfully advocated for the expansion of the welfare state (Lichtenstein, 2011). Although it has been criticized for supporting the Democratic Party, this alliance is not unfounded. Democrats are more likely to champion the policies unions seek (Rosenfeld, 2014).

Public sector unions exercise power by making contributions to political campaigns. For example, in the 2016 election cycle, public sector unions donated $\$ 59,837,282$ to federal candidates, parties, and outside groups. Roughly 89 percent of the contributions supported Democrats (Center for Responsive Politics, n.d. a). The top three contributors were the National Education Association (NEA), the American Federation of State County and Municipal Employees (AFSCME), and the American Federation of Teachers (AFT) (Center for Responsive Politics, n.d. b). The Service Employees International Union (SEIU), a hybrid union representing both public and private sector employees, contributed \$31,772,264 to federal candidates, parties, and outside groups in the 2016 election cycle (Center for Responsive Politics, n.d. c). 
In addition to monetary donations to candidates, public sector unions communicate with their members about policy issues and candidates' voting records. They encourage members to reach out to elected officials to discuss their concerns and engage in lobbying efforts to preserve public services, strengthen workers' rights, improve working conditions, secure fair wages, protect workers' safety, and safeguard the clientele they serve. In 2016 public sector unions spent $\$ 13,320,270$ on lobbying (Center for Responsive Politics, n.d. d).

Despite some bipartisan efforts, there is a long history of opposition to unions on the political right. Some of the early efforts to thwart unionism include creation of the National Right to Work Committee (NRTWC) in 1955. The NRTWC fought against what it defined as compulsory unionism (McCartin, 2012). As often happens in media discourse and public opinion (Gamson \& Modigliani, 1989), the NRTWC countered arguments for the right to join a union with arguments for the right to not join.

Although these efforts were initially aimed at private sector unions, over the past four decades anti-union forces on the right have strategized and mobilized to dismantle public sector collective bargaining rights. Borrowing policy from the NRTWC, the Public Service Research Council (PRSC) pursued similar tactics to limit collective bargaining in the public sector. In the early 1970s, the Republican Party opposed the creation of the National Public Employee Relations Act (NPERA) (Cantin, 2012).

Partisan politics played a role in restricting public employees' political activities through amendments to the Hatch Act in 1976, 1990, and 1993 (Gely \& Chandler, 2000). Specifically, 60 percent of Republicans in the House of Representatives and 75 percent of Republicans in the Senate voted against loosening restrictions on public employees' political activities. In contrast, 92 percent of Democrats in the House of Representatives and 96 percent of Democrats in the Senate supported the reform amendments (Gely \& Chandler, 2000). Thirty-five state governments have enacted similar restrictions, often referred to as little Hatch Acts, on public employees. These restrictions prohibit a variety of activities including taking an active part in political campaigns, providing or soliciting financial or staffing assistance to any political organization or candidate, and holding political positions while in government.

\subsection{Socioeconomic Context}

Following the financial crisis of 2008, opposition to public sector collective bargaining has intensified and spread to Northern industrial states such as Wisconsin, Michigan, Ohio and New Jersey. The conservative movement blamed public employees for state and local budget crises, contending that public employees' salaries and benefits outstripped compensation levels in private sector (Cantin, 2012). However, the data on public employees' compensation does not support these arguments.

Bender and Heywood (2010), Lewis and Galloway (2011), and Keefe (2012) demonstrate that, on average, state and local employees are slightly under-compensated compared to private sector workers. Estimates of the average rate of under-compensation range from 3.7 to 7.4 percent. The earnings disparity increases substantially for college educated workers. State and local governments pay college-educated workers on average 25 percent less than private employers (Keefe, 2012).

On the other hand, the public sector establishes a floor on compensation for workers with low levels of education. The compensation of workers with a high-school education or 
less tends to be higher for state and local government employees compared to similarly educated workers in the private sector (Keefe, 2012). Workers in this category are likely to be in low-skilled occupations such as groundskeepers, janitors, garbage collectors, and food service. These positions are often the first targets of outsourcing.

Even Democratic governors in New York and California joined the fray, claiming that public sector employees' benefits, especially pensions, were not sustainable and needed to be curtailed (McCartin, 2012). As of 2011, the shortfall for state and local government pension plans was estimated at $\$ 1$ trillion. The bulk of this shortfall, $\$ 850$ billion, may be attributed to the stock market collapse in 2007-2009. An additional $\$ 80$ billion of the shortfall is the result of state and local governments reducing or suspending their contributions to the funds during the economic crisis (Baker, 2011).

Overall this shortfall represents less than 0.2 percent of the state gross product over the next 30 years (Baker, 2011). Given that pension plans' investment returns involve a longtime horizon, correcting for these shortfalls is not an insurmountable task for most state and local governments. In fact, many of the attacks on public pension systems have been driven by The American Legislative Exchange Council (ALEC). ALEC is a conservative policy organization funded primarily by corporations, corporate trade groups, and corporate foundations. ALEC develops model legislation for weakening public programs and disseminates its plans to state and local government officials. Some of its most prominent corporate associates include: Koch Industries, Altria/Phillip Morris, Corrections Corporation of America, and Connections Academy (an online education corporation).

Although some public pensions have faced under-funding crises, the system as a whole provides security and cost-effective retirement options for employees and taxpayers. As of September 2015, state and local government pension systems held assets of \$3.56 trillion (National Association of State Retirement Administrators [NASRA], 2016). Over the period from 1990-2015, public pension funds have exceeded their assumed rate of investment returns despite the occurrence of three economic recessions and four years when median investment returns were negative (NASRA, 2016).

\subsection{State Political Systems}

In the U.S. states have the freedom to determine the structure of their legislatures. The number of members of the legislature, the length of terms, and legislative procedures and rules vary across states. Beginning in the 1960 s, there was a move to professionalize state legislatures to give them the capacity to address complex problems and to provide a counterbalance to the office of the governor.

The concept of professionalization measures the ability of legislators to make policy decisions. The key components of professionalization are legislators' compensation and benefits, time demands of service, and the staff and resources available to the legislators (Squire, 1988). Applying this concept, Squire and Moncrief (2015) categorized legislatures as professionalized (full-time service, relatively high salaries, and larger staff/better access to resources) and citizen (part-time services, lower salaries, fewer staff/resources).

The partisan composition of the legislatures and the executive branch matter. Republican governors have initiated radical civil service reforms. State legislatures are more likely to enact radical civil service reforms that strip public employees of workplace protections 
and expose them to political control by elected officials when the following conditions are present: Republicans are in control politically, their majority in the legislature is sizable, and public sector unions lack sufficient power to resist (McGrath, 2013).

\subsection{Labour Relations Policy Framework}

Given the failure to pass NPERA in the 1970s and the lack of subsequent national policies, public sector collective bargaining rights are set at state and local government levels and remain highly fragmented. The legal system governing collective bargaining for state and local government employees varies across the 50 states and within states. The end result is a patchwork system of collective bargaining (see Table 1). For example, 30 states and the District of Columbia have laws granting all public employees the right to bargain collectively, while 12 states limit collective bargaining rights to specific occupational categories.

Table 1: Status of Collective Bargaining Rights in the States, 2014

\begin{tabular}{llll}
\hline $\begin{array}{l}\text { Grant all public employ- } \\
\text { ees collective bargaining } \\
\text { rights }\end{array}$ & $\begin{array}{l}\text { Limit collective bargain- } \\
\text { ing rights to specific oc- } \\
\text { cupational categories }\end{array}$ & $\begin{array}{l}\text { Lack a policy permitting } \\
\text { collective bargaining }\end{array}$ & $\begin{array}{l}\text { Expressly prohibit collec- } \\
\text { tive bargaining }\end{array}$ \\
\hline $\begin{array}{l}\text { Alaska, California, Connecti- } \\
\text { cut, Delaware, Florida, Ha- }\end{array}$ & $\begin{array}{l}\text { Alabama, Colorado, Geor- } \\
\text { gia, Idaho, Indiana, Ken- }\end{array}$ & $\begin{array}{l}\text { Arkansas, Arizona, Loui- } \\
\text { siana, Mississippi, Oklaho- }\end{array}$ & North Carolina, Virginia \\
$\begin{array}{l}\text { waii, Illinois, lowa, Kansas, } \\
\text { tucky, Maryland, Nevada, } \\
\text { Maine, Massachusetts, }\end{array}$ & $\begin{array}{l}\text { Tennessee, Texas, Utah, } \\
\text { Michigan, Minnesota, }\end{array}$ & Wyoming & \\
Missouri, Montana, Nebras- & & \\
ka, New Hampshire, New & & \\
Jersey, New Mexico, & & \\
New York, North Dakota, \\
Ohio, Oregon, Pennsylvania, \\
Rhode Island, South Dakota, \\
$\begin{array}{l}\text { Vermont, Washington, West } \\
\text { Virginia, Wisconsin* }\end{array}$ \\
\hline
\end{tabular}

*Technically Wisconsin grants collective bargaining rights to all public employees. At the same time, a law passed in 2012 prohibits bargaining over working conditions and benefits, and restricts wage increases to changes in the Consumer Price Index.

Source: Data from state websites, legislative summaries, and various newspaper articles

Of the remaining eight states, six states lack a policy permitting public sector collective bargaining. However, informal bargaining often occurs in these states through meet and confer processes, local ordinance, and on an ad-hoc basis at the discretion of elected officials and administrators. The other two states, North Carolina and Virginia, have passed legislation specifically prohibiting collective bargaining (Kearney \& Mareschal, 2014). The multitude of bargaining structures established across states and localities through legislation, judicial decisions, and executive orders, results in highly decentralized bargaining. This in turn weakens the power of public sector unions. 


\section{Methods}

This study uses historical comparative analysis to examine the transformation of public sector industrial relations across all 50 states. It has two primary goals. The first is to observe and describe patterns that occur across cases. The second is to engage in theory building through the development of propositions (Miles \& Huberman, 1994; Yin, 2013) and the application of a conceptual framework (Miles \& Huberman, 1994).

Figure 1 provides the conceptual framework for analysing patterns of change across states. The key components of the model are the states' socioeconomic environment, political context, political system, labour relations policy, and public sector unionization. The focus here is on political context as measured by citizen ideology, political system as measured by professionalization of the legislature and control of the branches of government, labour relations policy framework as measured by new laws introduced and enacted, and changes in public sector unionization as measured by union density.

In the socioeconomic context tight budgets often lead to retrenchment of public employees' rights. In this regard, the financial crisis of 2008 impacted all state and local government budgets across the U.S. Proposition 1: The deflation of the housing bubble, the financial crisis of 2008, and the Great Recession served as shocks to the socio-economic environment of public sector unions. This opened the pathway for attacks on public sector unions.

Figure 1: A comprehensive model of state and local government unionization

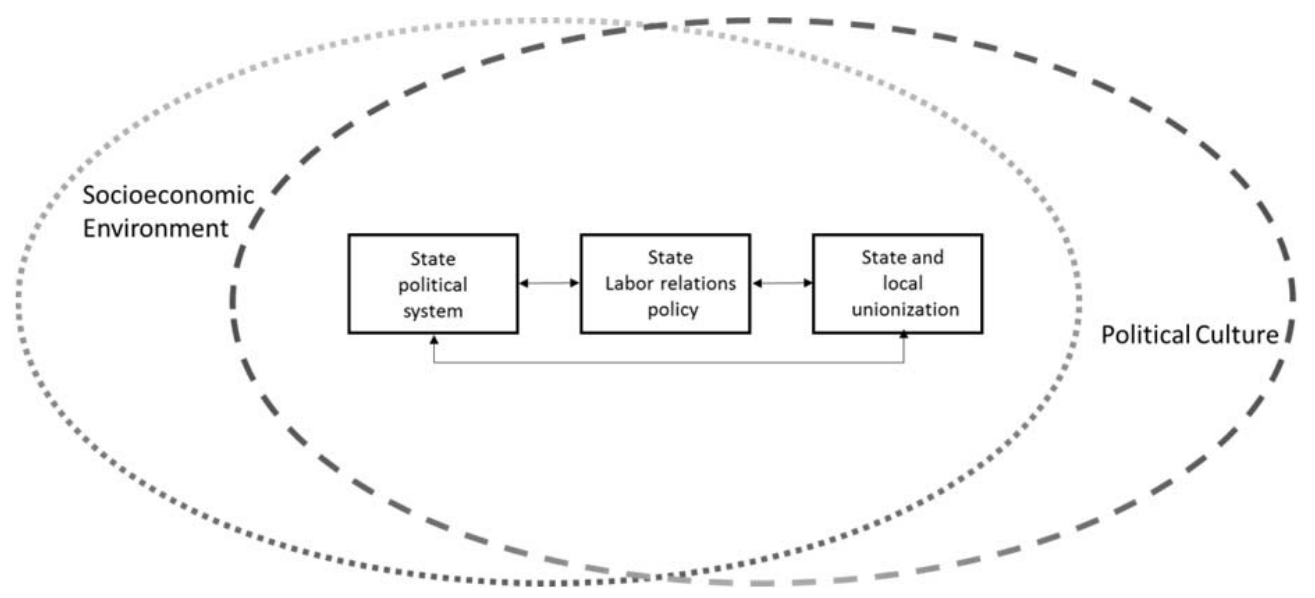

Source: Adapted from Kearney and Mareschal (2014)

The political culture of each state also plays a role. Political culture serves as a filter that influences individuals' positions on contentious policy issues. In the U.S., political culture spans the continuum between a hierarchical/individualist view of society at one end and an egalitarian/communitarian view at the other end (Hogler, Hunt \& Weiler, 2015). Specifically, it is expected that a shift toward a more conservative political culture will be associated with declining union density. Proposition 2: Changes in political culture will be associated 
with changes in collective bargaining rights. As a state's political culture becomes more conservative, public collective bargaining rights will be reduced. As a state's political culture becomes more liberal, public collective bargaining rights will be maintained or expanded.

The state political system is comprised of factors such as legislative professionalism, executive-legislative relations, and interparty competition. Legislative professionalization is an indicator of the legislative branch's ability to counterbalance the executive branch and make well-informed policy decisions. It is expected that professional legislatures will conduct independent policy analysis and therefore be less likely to be influenced by ALEC's model legislation. Proposition 3: Professional legislatures will preserve public sector collective bargaining rights and will be associated with stable union density. Proposition 4: It is expected that Republican control of all branches of government will be associated with attempts to reduce public sector collective bargaining rights and declining union density.

In terms of the labour relations policy framework, there is a clear connection between union membership and the scope of collective bargaining. States with the most comprehensive bargaining rights have the highest levels of unionization. Similarly, it is expected that the introduction and enactment of laws restricting public sector collective bargaining rights will be associated with declining union density. Although not every piece of legislation introduced at the state level is enacted, the continual need for unions to lobby against restrictive measures draws down the resources available to service members and conduct internal and external organizing. Proposition 5: The introduction and enactment of laws restricting public sector collective bargaining rights will be associated with declining union density.

\section{Results: Patterns Across the States}

The Great Recession sent tremors through the public sector union movement that continue to reverberate today. During the 2010 elections a faction calling itself the Tea Party gained power inside the Republican Party. The Tea Party faction drove the Republican Party further to the right of the political spectrum and accelerated attacks on civic institutions and social programs (Hogler, 2015). ALEC's model legislation served as the basis for many of the efforts to rescind public sector collective bargaining rights at the state and local levels.

Support for the Republican Party has been growing since the 1960s. The shifting balance of partisan support along with advancements in the Tea Party policy agenda hastened the weakening of collective bargaining rights. Table 2 shows changes in political ideology over the period of 2008-2013. Each state was evaluated with a possible range of scores from 0-100. Lower scores denote political conservatism; higher scores denote political liberalism. 
Table 2: Political Ideology 2008-2013

\begin{tabular}{|c|c|c|c|}
\hline $\begin{array}{l}\text { Conservative States } \\
2008 \text { Ideology Scores } \\
<50 \text { (listed from most } \\
\text { conservative to least } \\
\text { conservative) }\end{array}$ & $\begin{array}{l}2013 \text { Ideology Scores } \\
<50 \text { (listed from most } \\
\text { conservative to least } \\
\text { conservative) }\end{array}$ & $\begin{array}{l}\text { Liberal States } \\
2008 \text { Ideology Scores } \\
\text { > } 50 \text { (listed from most } \\
\text { liberal to least liberal) }\end{array}$ & $\begin{array}{l}2013 \text { Ideology Scores } \\
>50 \text { (listed from most } \\
\text { liberal to least liberal) }\end{array}$ \\
\hline Oklahoma & Utah & Massachusetts & Connecticut \\
\hline Wyoming & Oklahoma & Rhode Island & Vermont \\
\hline Idaho & Wyoming & Connecticut & Massachusetts \\
\hline Utah & Idaho & Vermont & Hawaii \\
\hline Georgia & Arkansas & Hawaii & Rhode Island \\
\hline Mississippi & Kansas & New York & Maine \\
\hline Kansas & Nebraska & Maine & New York \\
\hline Louisiana & Alabama & New Jersey & Delaware \\
\hline Nebraska & Tennessee & West Virginia & Maryland \\
\hline South Carolina & Texas & Maryland & Alaska \\
\hline Alabama & Indiana & Delaware & New Jersey \\
\hline Arizona & Kentucky & Oregon & California \\
\hline \multirow[t]{25}{*}{ Texas } & South Carolina & Illinois & New Mexico \\
\hline & Louisiana & Pennsylvania & Oregon \\
\hline & Georgia & Washington & Michigan \\
\hline & North Carolina & Michigan & Washington \\
\hline & South Dakota & Minnesota & Pennsylvania \\
\hline & lowa & New Mexico & Illinois \\
\hline & North Dakota & North Dakota & Minnesota \\
\hline & Missouri & Ohio & New Hampshire \\
\hline & Florida & California & \\
\hline & Arizona & Wisconsin & \\
\hline & Virginia & Missouri & \\
\hline & Mississippi & Alaska & \\
\hline & Nevada & Montana & \\
\hline & Wisconsin & Virginia & \\
\hline & West Virginia & Arkansas & \\
\hline & Colorado & Nevada & \\
\hline & Ohio & lowa & \\
\hline & Montana & Florida & \\
\hline & & North Carolina & \\
\hline & & South Dakota & \\
\hline & & Colorado & \\
\hline & & Indiana & \\
\hline & & New Hampshire & \\
\hline & & Tennessee & \\
\hline & & Kentucky & \\
\hline
\end{tabular}

Source: Adapted from Berry, Fording, Ringquist, and Hanson (2015).

https://rcfording.wordpress.com/state-ideology-data/

State scores under 50 were determined to be politically conservative and scores above 50 were determined to be politically liberal. During the period, the number of states with conservative ideology grew from 13 in 2008 to 30 in 2013. Between 2008 and 2013 political ideology scores became more conservative in all but four states. The mean score decreased by 9.48 points, from 59.32 in 2008 to 49.84 in 2013 . 
The evidence does not fully support Proposition 2 . Of the 30 politically conservative states, 17 experienced a decline in union density and two experienced no change in union density. Unexpectedly, union density increased in 11 of the politically conservative states.

The National Conference of State Legislatures (NCSL) modifies schema for classifying state legislatures developed by Squire and Moncrief (2015) to include an intermediate category. Using this modified schema, legislatures are categorized as Green (full-time, wellpaid, large staff), Gray (hybrid), and Gold (part-time, low pay, small staff) (National Conference of State Legislatures [NCSL], 2014). Table 3 shows the distribution of states along this schema.

Table 3: Types of Legislatures

\begin{tabular}{lll}
\hline Green/Professional & Gray/Hybrid & Gold/ Citizen \\
\hline California, New York, Pennsylvania & Alabama, Arizona, Arkansas, Colorado, & Montana, New Hampshire, North Dako- \\
Alaska, Florida, Illinois, Massachusetts, & Connecticut, Delaware, Hawaii, Indiana, ta, South Dakota, Utah, Wyoming \\
Michigan, Ohio, Wisconsin & lowa, Kentucky, Louisiana, Maryland, Georgia, Idaho, Kansas, Maine, Missis- \\
& Minnesota, New Jersey, Missouri, Ne- & sippi, Nevada, New Mexico, Rhode Is- \\
& braska, North Carolina, Oklahoma, Or- & land, Vermont, West Virginia \\
& egon, South Carolina, Tennessee, Tex- \\
& as, Virginia, Washington \\
\hline
\end{tabular}

Adapted from: Full- and Part-Time Legislatures, NCSL (2014) http://www.ncsl.org/research/aboutstate-legislatures/full-and-part-time-legislatures.aspx\#green

Within the Green/Professional category, three states have longer legislative sessions and larger districts. These are California, New York, and Pennsylvania. All three experienced moderate declines in union density. Thus, the evidence did not support Proposition 3.

As of March 2017, Republicans controlled 32 state legislatures, 33 state governorships and had party control (both legislative and governorship) of 24 states. Democrats controlled 14 legislatures and 16 governorships with party control of seven states. The states of Colorado, Connecticut, and Maine had split legislatures, and Nebraska has a non-partisan unicameral legislature. Additionally, one state, Alaska, had an independent governor. Table 4 shows the distribution of states by political control.

The evidence provides weak support for proposition 4. Of the 24 states with Republican control of the legislature and governorship, 13 experienced a decline in union density, two experienced no change in union density, and nine experienced increases in union density.

The states of Indiana, Wisconsin, Ohio, and Michigan were at the forefront of the rollback of public sector collective bargaining rights. These states passed laws that eliminated collective bargaining for entire classes of employees, limited the scope of bargaining, made it more difficult to collect dues from members, removed the requirement that non-members pay a representation/agency fee, and created multiple barriers to union activity. 
Table 4: State Party Control 2017

\begin{tabular}{|c|c|c|}
\hline \multicolumn{3}{|c|}{ State Party Control ${ }^{a}$} \\
\hline Democratic Control & Republican Control & Divided \\
\hline $\begin{array}{l}\text { California } \\
\text { Delaware } \\
\text { Hawaii } \\
\text { New York } \\
\text { Oregon } \\
\text { Rhode Island } \\
\text { Washington }\end{array}$ & $\begin{array}{l}\text { Alabama } \\
\text { Arizona } \\
\text { Arkansas } \\
\text { Florida } \\
\text { Georgia } \\
\text { Idaho } \\
\text { Indiana } \\
\text { lowa } \\
\text { Kansas } \\
\text { Kentucky } \\
\text { Michigan } \\
\text { Mississippi } \\
\text { Missouri } \\
\text { New Hampshire } \\
\text { North Dakota } \\
\text { Ohio } \\
\text { Oklahoma } \\
\text { South Carolina } \\
\text { South Dakota } \\
\text { Tennessee } \\
\text { Texas } \\
\text { Utah } \\
\text { Wisconsin } \\
\text { Wyoming }\end{array}$ & $\begin{array}{l}\text { Alaska } \\
\text { Colorado } \\
\text { Connecticut } \\
\text { Illinois } \\
\text { Louisiana } \\
\text { Maine } \\
\text { Maryland } \\
\text { Massachusetts } \\
\text { Minnesota } \\
\text { Montana } \\
\text { Nebraska } \\
\text { Nevada } \\
\text { New Jersey } \\
\text { New Mexico } \\
\text { North Carolina } \\
\text { Pennsylvania } \\
\text { Vermont } \\
\text { Virginia } \\
\text { West Virginia }\end{array}$ \\
\hline
\end{tabular}

${ }^{\text {a }}$ Derived from National Conference of State Legislatures (NCSL) 2017 State \& Legislative Partisan Composition, March 1, 2017, 9 am, http://www.ncsl.org/portals/1/documents/ elections/Legis_Control_2017_March_1_9\%20am.pdf.

*Notes: Alaska House - controlled by coalition w/Democratic functional control; Connecticut Senate - Lieutenant Governor Wyman (Democrat) casts tie-breaking votes; Nebraska - Unicameral, nonpartisan legislature; New York Senate - controlled by coalition w/Republican functional control; Washington Senate - controlled by coalition w/Republican functional control; Vermont's House - includes 6 Independents and 7 Progressives.

Although favourable laws and policies alone are not enough to spur union growth, restrictive laws and policies can weaken unions (Goldfield \& Bromsen, 2013). The early adopters of anti-union legislation set the pattern that other states and local governments followed. Labour unions responded to the assault on public sector collective bargaining rights in various ways including public protests, election recalls, ballot initiatives, and court challenges. These efforts had mixed results. Public sector unions in Wisconsin accomplished recalls of five legislators, but the effort to recall Governor Walker was unsuccessful. Public sector unions in Ohio formed a coalition and successfully repealed the restrictive law through a popular referendum. However, both Michigan and Wisconsin subsequently passed right-to-work legislation.

Table 5 demonstrates the relentless efforts to undermine public sector collective bargaining rights over the period of 2011-2016. The NCSL identifies 14 categories of legislation related to collective bargaining. Some bills fall under multiple categories and/or are carried over from year-to-year. These increased counts are reflected in the data. 
Table 5: Anti-Union Legislation Introduced 2011-2016

\begin{tabular}{|c|c|c|c|c|c|}
\hline State & Negotiations & Wages/Benefits & $\begin{array}{l}\text { Right-to-Work/ } \\
\text { Membership }\end{array}$ & $\begin{array}{l}\text { Dues Collection/ } \\
\text { Agency Fee }\end{array}$ & $\begin{array}{c}\text { Political Activities/ } \\
\text { Contributions }\end{array}$ \\
\hline Alabama & 0 & 0 & 6 & 0 & 0 \\
\hline Alaska & 0 & 4 & 2 & 3 & 6 \\
\hline Arizona & 3 & 2 & 8 & 21 & 9 \\
\hline Arkansas & 1 & 1 & 0 & 0 & 0 \\
\hline California & 8 & 23 & 3 & 11 & 8 \\
\hline Colorado & 0 & 0 & 6 & 2 & 0 \\
\hline Connecticut & 2 & 6 & 5 & 7 & 4 \\
\hline Delaware & 1 & 1 & 2 & 0 & 0 \\
\hline Florida & 6 & 1 & 0 & 3 & 2 \\
\hline Georgia & 0 & 0 & 3 & 1 & 0 \\
\hline Hawaii & 14 & 296 & 11 & 7 & 1 \\
\hline Idaho & 3 & 0 & 0 & 2 & 1 \\
\hline Illinois & 19 & 29 & 15 & 11 & 6 \\
\hline Indiana & 0 & 2 & 8 & 8 & 2 \\
\hline lowa & 6 & 16 & 9 & 22 & 3 \\
\hline Kansas & 4 & 0 & 2 & 4 & 4 \\
\hline Kentucky & 0 & 2 & 4 & 0 & 0 \\
\hline Louisiana & 0 & 0 & 0 & 2 & 0 \\
\hline Maine & 4 & 5 & 22 & 20 & 6 \\
\hline Maryland & 1 & 4 & 10 & 9 & 1 \\
\hline Massachusetts & 22 & 16 & 8 & 28 & 3 \\
\hline Michigan & 3 & 20 & 7 & 24 & 6 \\
\hline Minnesota & 4 & 11 & 3 & 16 & 3 \\
\hline Mississippi & 0 & 0 & 2 & 1 & 0 \\
\hline Missouri & 1 & 0 & 42 & 30 & 11 \\
\hline Montana & 2 & 0 & 7 & 6 & 1 \\
\hline Nebraska & 0 & 0 & 0 & 2 & 2 \\
\hline Nevada & 4 & 2 & 1 & 3 & 0 \\
\hline New Hampshire & 14 & 5 & 31 & 33 & 4 \\
\hline New Jersey & 16 & 19 & 13 & 20 & 28 \\
\hline New Mexico & 0 & 1 & 8 & 6 & 0 \\
\hline New York & 16 & 30 & 8 & 4 & 2 \\
\hline North Carolina & 0 & 0 & 5 & 5 & 0 \\
\hline North Dakota & 1 & 0 & 0 & 1 & 0 \\
\hline Ohio & 0 & 0 & 9 & 9 & 2 \\
\hline Oklahoma & 0 & 0 & 2 & 11 & 1 \\
\hline Oregon & 1 & 7 & 1 & 3 & 1 \\
\hline Pennsylvania & 5 & 8 & 15 & 31 & 10 \\
\hline Rhode Island & 4 & 16 & 8 & 10 & 1 \\
\hline South Carolina & 0 & 0 & 6 & 6 & 2 \\
\hline South Dakota & 0 & 0 & 2 & 4 & 0 \\
\hline Tennessee & 2 & 1 & 6 & 14 & 10 \\
\hline Texas & 0 & 1 & 0 & 4 & 4 \\
\hline Utah & 1 & 1 & 0 & 3 & 0 \\
\hline Vermont & 4 & 7 & 0 & 6 & 5 \\
\hline Virginia & 0 & 1 & 15 & 2 & 0 \\
\hline Washington & 7 & 8 & 7 & 5 & 0 \\
\hline West Virginia & 0 & 0 & 12 & 2 & 2 \\
\hline Wisconsin & 4 & 9 & 4 & 8 & 4 \\
\hline Wyoming & 0 & 0 & 0 & 0 & 1 \\
\hline Totals & 183 & 555 & 338 & 430 & 156 \\
\hline
\end{tabular}

Source: NCSL Collective Bargaining and Labor Union Legislation Database 
Table 6: Changes in State Union Density 2008-2015

\begin{tabular}{|c|c|c|c|}
\hline State & 2008 & 2015 & Change \\
\hline Alabama & 29.8 & 33.8 & 4 \\
\hline Alaska & 55.6 & 41.8 & -13.8 \\
\hline Arizona & 19.2 & 17.0 & -2.2 \\
\hline Arkansas & 16.0 & 15.6 & -0.4 \\
\hline California & 57.3 & 55.0 & -2.3 \\
\hline Colorado & 22.0 & 17.0 & -5 \\
\hline Connecticut & 63.0 & 65.6 & 2.6 \\
\hline Delaware & 38.7 & 34.9 & -3.8 \\
\hline Florida & 28.0 & 27.5 & -0.5 \\
\hline Georgia & 8.7 & 11.5 & 2.8 \\
\hline Hawaii & 54.3 & 50.0 & -4.3 \\
\hline Idaho & 16.7 & 18.4 & 1.7 \\
\hline Illinois & 50.3 & 53.2 & 2.9 \\
\hline Indiana & 27.4 & 27.4 & 0 \\
\hline lowa & 31.3 & 27.6 & -3.7 \\
\hline Kansas & 16.6 & 22.9 & 6.3 \\
\hline Kentucky & 16.3 & 23.7 & 7.4 \\
\hline Louisiana & 13.3 & 16.9 & 3.6 \\
\hline Maine & 45.2 & 50.8 & 5.6 \\
\hline Maryland & 30.9 & 28.8 & -2.1 \\
\hline Massachusetts & 61.0 & 59.2 & -1.8 \\
\hline Michigan & 57.3 & 48.4 & -8.9 \\
\hline Minnesota & 55.0 & 47.4 & -7.6 \\
\hline Mississippi & 9.4 & 9.4 & 0 \\
\hline Missouri & 23.3 & 22.1 & -1.2 \\
\hline Montana & 38.5 & 35.8 & -2.7 \\
\hline Nebraska & 27.3 & 25.9 & -1.4 \\
\hline Nevada & 36.5 & 32.4 & -4.1 \\
\hline New Hampshire & 47.8 & 46.7 & -1.1 \\
\hline New Jersey & 62.1 & 56.0 & -6.1 \\
\hline New Mexico & 16.0 & 13.8 & -2.2 \\
\hline New York & 70.5 & 68.6 & -1.9 \\
\hline North Carolina & 11.0 & 10.1 & -0.9 \\
\hline North Dakota & 16.3 & 14.8 & -1.5 \\
\hline Ohio & 40.6 & 38.4 & -2.2 \\
\hline Oklahoma & 18.0 & 15.4 & -2.6 \\
\hline Oregon & 59.9 & 50.8 & -9.1 \\
\hline Pennsylvania & 52.9 & 49.9 & -3 \\
\hline Rhode Island & 61.9 & 61.8 & -0.1 \\
\hline South Carolina & 10.9 & 7.2 & -3.7 \\
\hline South Dakota & 16.6 & 22.8 & 6.2 \\
\hline Tennessee & 16.0 & 19.0 & 3 \\
\hline Texas & 15.0 & 16.6 & 1.6 \\
\hline Utah & 15.5 & 12.5 & -3 \\
\hline Vermont & 40.2 & 50.7 & 10.5 \\
\hline Virginia & 9.3 & 13.7 & 4.4 \\
\hline Washington & 51.0 & 46.1 & -4.9 \\
\hline West Virginia & 25.3 & 26.3 & 1 \\
\hline Wisconsin & 47.7 & 26.1 & -21.6 \\
\hline Wyoming & 13.2 & 13.7 & 0.5 \\
\hline
\end{tabular}

Source: Barry T. Hirsch and David A. Macpherson (2016) Union Membership, Coverage, Density, and Employment by State and Sector, 1983-2015, http://www.unionstats.com/ 
The focus here is on the categories most detrimental to public sector unions' viability. These include: negotiations, wages/benefits, right-to-work/membership, dues/agency fee, and political contributions. It is expected that the legislation in these categories negatively impacts unions' ability to represent, recruit and retain members, collect dues, and exercise political power.

During this period, bills were introduced with restrictions in the following areas: negotiations (183), wages/benefits (555), right-to-work/membership (338), dues/agency fee (430), and political activities/contributions (156). The total number of occurrences of attempts to restrict collective bargaining during this period was 1662 . The number of attempts per state ranges from one to 329. The average number of bills per state was 33 .

The following 14 states (ranked lowest to highest) had above average numbers of attempts to modify public sector collective bargaining rights: Minnesota, Rhode Island, Arizona, Iowa, Maine, Michigan, New York, Pennsylvania, Massachusetts, Illinois, Missouri, New Hampshire, New Jersey, Hawaii. Of these states, 12 experienced a decline in union density. Thus, the evidence supports proposition 5 .

Around the world union density has decreased due to a decline in manufacturing and the replacement of workers by technology (Wilson, 2012). In the U.S., the decline in union density has been even more pronounced due to the failure of the American state to protect collective bargaining rights and the willingness to implement austerity measures. State and local governments eliminated approximately 730,000 jobs between 2007 and 2013. Overall, public sector union density dropped from 36.5 in 2008 to 35.2 in 2015 (Bureau of Labor Statistics, 2009, 2016).

The degree of loss varies from state to state. Table 6 shows the change in union density for all 50 states. From 2008 to 2015 union density declined in 32 states. Some of the steepest declines were in northern and western states that had previously been union-friendly such as Wisconsin (-21.6), Alaska (-13.8), Oregon (-9.1), Michigan (-8.9), Minnesota (7.6), and New Jersey (-6.1). Union density remained constant in two states and increased in 16 states, with Vermont showing a gain of 10 percentage points.

\section{Discussion and Conclusion}

Although it is not possible to establish causation, it is clear that the changes in the socioeconomic environment, political culture, and labour relations policy context are related to changes in state and local unionization. Public sector unions in the U.S. face a number of ongoing threats and challenges. First, the strength of public employees and public sector unions made them a prime target of the conservative right. Unlike private sector employees who forfeit their citizenship rights on acceptance of employment, public sector employees in the U.S. retain their constitutional and civil rights in the work place, as well as property rights to their jobs.

Second, public sector unions play a critical role in policymaking at all levels of government through political activities. These include policy advocacy, contributions to political campaigns, participation in voter turnout drives, and the exercise of discretion in implementing policies. Yet, politicians and conservative interest groups have portrayed public 
sector unions as obstacles to government effectiveness and efficiency whose participation and influence on policies should be restricted.

Public sector jobs have provided a career ladder for women and racial minorities. Traditionally public sector employment has provided job security. This benefits public sector employers by facilitating efficiency and continuity in service delivery. It also benefits workers by providing uninterrupted material benefits and protection from arbitrary dismissals (Peters, 2001). The retrenchment of civil service protections and collective bargaining rights will increase both groups' vulnerability to discriminatory job dismissals and will most likely increase gender and racial inequality in public employment.

The decline of unions harms all workers. Over the period of 1973-2007 union membership declined in the U.S. During the same timeframe, wage inequality increased by 40 percent (Western \& Rosenfeld, 2011). Rising inequality has impacted less-educated, blue-collar, male workers most severely. This group of workers is particularly resentful of the progress women, African Americans, and public sector workers have made (Hochschild, 2016).

In addition to raising wages, unions promote norms of equity. They do this in three important ways. From a cultural perspective, unions foster a public discussion about economic equality. From a political perspective, unions influence social policies. From an institutional perspective, unions establish rules that guide the labour market (Western \& Rosenfeld, 2011).

If public sector unions are to survive, they will need to help rebuild strength in private sector unions, so that displaced private sector workers do not see good jobs for public sector workers as a threat to their own financial wellbeing. Increasingly unions will have to devote more resources to political and legislative lobbying due to competition from other interest groups and to policy challenges at the state, local, and federal levels such as rightto-work laws. The passage of right-to-work legislation in Missouri in 2017 is the most recent example of the continued onslaught. Public sector unions will also need to advocate for both labour-specific issues and broader social issues.

Although alternative labour groups have waged successful campaigns to advocate for a living wage and improvements in working conditions for hard-to-organize groups such as fast-food employees, retail employees, taxi drivers, and car wash workers, labour unions remain the most prominent non-market institution promoting voice at work and economic justice. Like any other institution, public sector unions are imperfect. Critics contend that they wield inordinate political power and put their own interests above the public good.

At the same time, the potential for abuse is counterbalanced by legal constraints designed to prevent public sector unions from becoming too powerful. For example, little Hatch acts limit public employees' political activities and campaign finance laws place restrictions on unions' abilities to contribute to political action committees. Interestingly, some of public sector unions' most visible victories in recent years have been in specific cases where unions formed coalitions with community members to promote the public good, such as the Oregon SEIU Local 503's approach to bargaining which includes demands for undergraduate tuition caps and the Chicago Teachers Union's successful 2012 campaign for smaller classes and better student support services.

The erosion of formalized collective bargaining rights undermines the ability of unions, alternative labour groups, and community coalitions to participate in democratic processes. 
Working conditions, standards of living, and participation in civil society and the political arena, are issues of public concern and elements of full citizenship. Public sector unions will have to make the case that all workers benefit from full citizenship rights and the raceto-the-bottom approach degrades all workers. Government should be a model employer. If government does not respect basic norms of fairness, constitutional rights, and citizenship rights for its own workers, how can it compel private sector employers to abide by policies intended to ensure fairness in the workplace and protect workers' rights such as wage and hour laws, health and safety regulations, and anti-discrimination provisions? By promoting full citizenship rights for all, public sector unions may be able to restore a more equitable balance of power between workers and management that is necessary for a robust political democracy.

\section{References}

Autor, D. (2010). The polarization of job opportunities in the US labor market: Implications for employment and earnings. Center for American Progress and The Hamilton Project.

Baker, D. (2011). Origins and Severity of the Public Pension Crisis. Washington, DC: Center for Economic and Policy Research.

Barratt, C. (2009). Trade Union Membership: 2008. Department for Business, Enterprise and Regulatory Reform.

Barrett, T. (1973). Prospects for Growth and Bargaining in the Public Sector. Government Employee Relations Report, 534, F1-F4.

Barzelay, M. (2001). The new public management: Improving research and policy dialogue (Vol. 3). University of California Press.

Bender, K. A. \& Heywood, J. S. (2010). Comparing public and private sector compensation over 20 years. Washington, DC: Center for State and Local Government Excellence and National Institute on Retirement Security.

Berry, W. D., Ringquist, E. J., Fording, R. C. \& Hanson, R. L. (2015). Updated and revised citizen and government ideology measures through 2013/2014. Retrieved from https://rcfording.wordpress.com/state-ideology-data/.

Bradbury, M. D. \& Waechter, G. D. (2009). Extreme outsourcing in local government: At the top and all but the top. Review of Public Personnel Administration, 29 (3), 230-248. doi: $10.1177 / 0734371 \times 09332572$

Brewer, G. A. \& Kellough, J. E. (2016). Administrative values and public personnel management: reflections on civil service reform. Public Personnel Management, 45 (2), 171-189. doi:10.1177/0091026016644626

Bureau of Labor Statistics, U.S. Department of Labor (2009). News Release, Union members in 2008. Retrieved from https://www.bls.gov/news.release/archives/union2_01282009.pdf

Bureau of Labor Statistics, U.S. Department of Labor (2016). News Release, Union members in 2015. Retrieved from https://www.bls.gov/news.release/archives/union2_01282016.pdf

Cantin, E. (2012). The politics of austerity and the conservative offensive against US public sector unions, 2008-2012. Relations Industrielles/Industrial Relations, 67 (4), 612-632. doi:10.7202/1013197ar

Carter, B. \& Fairbrother, P. (1999). The transformation of British public-sector industrial relations: from 'model employer' to marketized relations. Historical Studies in Industrial Relations (7, Spring 1999), 119-146. doi:10.3828/hsir.1999.7.6

Center for Responsive Politics. (n.d. a). Public Sector Unions: Long-Term Contribution Trends. Retrieved from https://www.opensecrets.org/industries/totals.php?ind=P04 
Center for Responsive Politics. (n.d. b). Public Sector Unions. Retrieved from https://www.opensecrets.org/industries/indus.php?cycle=2016\&ind=P04

Center for Responsive Politics. (n.d. c). Service Employees International Union. Retrieved from https://www.opensecrets.org/orgs/summary.php?id=D000000077

Center for Responsive Politics. (n.d. d). Public Sector Unions: Lobbying. Retrieved from https://www.opensecrets.org/industries/lobbying.php?cycle=2016\&ind=P04

Corby, S. \& Symon, G. (2011). From New Labour to a new era? In S. Corby \& G. Symon (Eds.), Working for the State. Employment Relations in the Public Services (pp. 3-20). Palgrave Macmillan UK. doi:10.1057/9780230347984_1

Current Population Survey Outgoing Rotation Group microdata. (2014). Survey conducted by the Bureau of the Census for the Bureau of Labor Statistics [machine-readable microdata file]. U.S. Census Bureau.

Dixon, M. \& Martin, A. W. (2012). We can't win this on our own: Unions, firms, and mobilization of external allies in labor disputes. American Sociological Review, 77 (6), 946-969. doi: $10.1177 / 0003122412460649$

Fernandez, S., Smith, C. R. \& Wenger, J. B. (2007). Employment, privatization, and managerial choice: Does contracting out reduce public sector employment? Journal of Policy Analysis and Management, 26 (1), 57-77. doi:10.1002/pam.20227

Freeman, R. B. \& Kleiner, M. M. (1990). Employer behavior in the face of union organizing drives. ILR Review, 43 (4), 351-365. doi:10.3386/w2805

Gamson, W. A. \& Modigliani, A. (1989). Media discourse and public opinion on nuclear power: A constructionist approach. American Journal of Sociology, 95 (1), 1-37. doi:10.1086/229213

Gely, R. \& Chandler, T. D. (2000). Restricting public employees' political activities: Good government or partisan politics. Houston Law Review, 37, 775.

Goldfield, M. \& Bromsen, A. (2013). The changing landscape of US unions in historical and theoretical perspective. Annual Review of Political Science, 16, 231-257. doi:10.1146/annurev-polisci-032211-214003

Goldfield, M. (1989). The decline of organized labor in the United States. University of Chicago Press.

Goos, M., Manning, A. \& Salomons, A. (2009). Job polarization in Europe. The American Economic Review, 99 (2), 58-63. doi:10.1257/aer.99.2.58

Hansen, J. (1995). Editorial: Merit in Personnel Reform. The Atlanta Journal and The Atlanta Constitution, 1995/14, 16.

Hefetz, A., Warner, M. E. \& Vigoda-Gadot, E. (2012). Privatization and intermunicipal contracting: the US local government experience 1992-2007. Environment and Planning C: Government and Policy, 30 (4), 675-692. doi:10.1068/c11166

Hirsch, B. \& Macpherson, D. (2016). Union Membership, Coverage, Density, and Employment by State and Sector, 1983-2015, Retrieved from http://www.unionstats.com/

Hochschild, A. R. (2016). Strangers in their own land: Anger and mourning on the American right. New York, London: The New Press.

Hogler, R. L. (2015). The End of American Labor Unions: The Right-to-Work Movement and the Erosion of Collective Bargaining. Santa Barbara: ABC-CLIO.

Hood, C. (1991). A public management for all seasons? Public Administration, 69 (1), 3-19. doi:10.1111/j.1467-9299.1991.tb00779.x

Hyman, R. (2005). Trade unions and the politics of the European social model. Economic and Industrial Democracy, 26 (1), 9-40. doi: 10.1177/0143831X05049401

Jordan, T. \& Battaglio Jr, R. P. (2014). Are we there yet? The state of public human resource management research. Public Personnel Management, 43 (1), 25-57. doi:10.1177/0091026013511064 
Kearney, R. C. \& Hays, S. W. (1998). Reinventing government, the new public management and civil service systems in international perspective: The danger of throwing the baby out with the bathwater. Review of Public Personnel Administration, 18 (4), 38-54. doi:10.1177/0734371x9801800404

Kearney, R. C. \& Mareschal, P. M. (2014). Labor relations in the public sector. Boca Raton: crc Press.

Keefe, J. (2012). Are public employees overpaid? Labor Studies Journal, 37 (1), 104-126. doi:10.1177/0160449X11429263

Lewin, D., Kochan, T. \& Keefe, J. (2012). Toward a new generation of empirical evidence and policy research on public sector unionism and collective bargaining. Champaign, IL: Employment Policy Research Network.

Lewis, G. B. \& Galloway, C. S. (2011). A national analysis of public/private wage differentials at the state and local levels by race and gender. SSRN Electronic Journal. doi:10.2139/ssrn. 1768190

Lichtenstein, N. (2011). Labour, liberalism, and the Democratic Party: A vexed alliance. Relations Industrielles/Industrial Relations, 66 (4), 512-534. doi:10.7202/1007631ar

Malin, M. H. (2012). Does Public Employee Collective Bargaining Distort Democracy: A Perspective from the United States? Comparative Labor Law Journal \& Policy Journal, 34, 277.

Matthews, D. (2010). The changing face of public sector employment 1999-2009. Economic \& Labour Market Review, 4 (7), 28-35. doi:10.1057/elmr.2010.94

McCartin, J. A. (2006). Bringing the state's workers in: Time to rectify an imbalanced US labor historiography. Labor History, 47 (1), 73-94. doi:10.1080/00236560500385934

McCartin, J. A. (2012). Beyond human rights: Understanding and addressing the attack on public sector unions. Human Rights Review, 13 (3), 399-403. doi:10.1007/s12142-012-0234-2

McGrath, R. J. (2013). The rise and fall of radical civil service reform in the US states. Public Administration Review, 73 (4), 638-649. doi:10.1111/puar.12075

Miles, M. B. \& Huberman, A. M. (1994). Qualitative data analysis: An expanded sourcebook. Sage Publications Ltd.

Morse, R. S. (2008). Developing public leaders in an age of collaborative governance. In R. S. Morse \& T. F. Buss (Eds.), Innovations in public leadership development (pp. 79-100). London: Routledge.

National Association of State Retirement Administrators. (2016). NASRA Issue Brief: State and Local Government Spending on Public Employee Retirement Systems. Retrieved from http://www.nasra.org/files/Issue\%20Briefs/NASRACostsBrief.pdf

National Conference of State Legislatures. (2014). Full- and Part-time Legislatures. Retrieved from http://www.ncsl.org/research/about-state-legislatures/full-and-part-time-legislatures.aspx

National Conference of State Legislatures. (2017). State and Legislative Partisan Composition. Retrieved from http://www.ncsl.org/portals/1/documents/elections/Legis_Control_2017_March_1_9\%20am.pdf

National Conference of State Legislatures. (n.d.). Collective Bargaining and Labor Union Legislation Database, 2011-2016. Retrieved from

http://www.ncsl.org/research/labor-and-employment/collective-bargaining-legislationdatabase.aspx

Peters, B. G. (2001). The future of governing. Lawrence: University Press of Kansas.

Rosenfeld, J. (2014). What unions no longer do. Cambridge: Harvard University Press.

Ross, S. \& Savage, L. (2013). Introduction: Public sector unions in the age of austerity. In S. Ross \& L. Savage (Eds.), Public Sector Unions in the Age of Austerity. (pp. 9-17) Halifax \& Winnipeg: Fernwood Publishing.

Ryan, C. \& Bauman, K. (2016). Educational Attainment in the United States: 2015. U.S. Census Bureau. Retrieved from https://www.census.gov/content/dam/Census/library/publications/2016/demo/p20-578.pdf 
Slater, J. E. (2013). The Strangely Unsettled State of Public-Sector Labor in the Past Thirty Years. Hofstra Labor \& Employment Law Journal, 30 (2), Article 10. Retrieved from http://scholarlycommons.law.hofstra.edu/hlelj/vol30/iss2/1

Squire, P. \& Moncrief, G. (2015). State legislatures today: Politics under the domes. Rowman \& Littlefield.

Squire, P. (1988). Career opportunities and membership stability in legislatures. Legislative Studies Quarterly, 13 (1), 65-82. doi:10.2307/439945

Western, B. \& Rosenfeld, J. (2011). Unions, norms, and the rise in US wage inequality. American Sociological Review, 76 (4), 513-537. doi:10.1177/0003122411414817

Wilson, G. K. (2012). American Unions in Comparative Perspective. The Forum, 10 (1), Article 10. doi: $10.1515 / 1540-8884.1504$

Yin, R. K. (2013). Case study research: Design and methods (5th). Los Angeles: Sage publications. 
DuEPublico

\section{Duisburg-Essen Publications online}

UNIVERSITÄT

DE USSEBN R G

offen im Denken

$\mathbf{U b} \mid \begin{aligned} & \text { universitäts } \\ & \text { bibliothek }\end{aligned}$

This text is made available via DuEPublico, the institutional repository of the University of

Duisburg-Essen. This version may eventually differ from another version distributed by a commercial publisher.

DOI: $\quad 10.3224 /$ indbez.v24i4.05

URN: urn:nbn:de:hbz:464-20200703-074836-5

This work may be used under a Creative Commons AttributionShareAlike 4.0 License (CC BY-SA 4.0). 